\title{
Status prawny sędziego w Zjednoczonym Królestwie Wielkiej Brytanii i Irlandii Północnej
}

\section{Wprowadzenie}

Wielka Brytania jest krajem wysoko rozwiniętym ze znacznymi wpływami politycznymi na arenie międzynarodowej. Ustrój brytyjski należy traktować jako wypadkową zasady suwerenności parlamentu, zasady rządów prawa i zasady podziału władz ${ }^{1}$. Parlament jest trójczłonowy i składa się z Izby Gmin (ang. House of Commons), Izby Lordów (ang. House of Lords) i monarchy. House of Lords ma jedynie ograniczoną możliwość opóźnienia uchwał demokratycznie wybranej House of Commons. Władzę wykonawczą sprawuje Gabinet (ang. Cabinet) składający się z premiera oraz najważniejszych ministrów. Są oni wybierani z partii stanowiącej większość w Parlamencie. Władza sądownicza jest gałęzią niezależną. Poza Anglią, pozostałe kraje posiadają również własne lokalne organy rządowe.

System prawny w Wielkiej Brytanii różni się od systemów prawnych w Europie kontynentalnej, które opierają się na prawie rzymskim. Prawo angielskie ma swoje podstawy w prawie precedensowym (ang. common $l a w)^{2}$ i polega na oparciu norm prawnych i rozstrzygnięć sądowych na precedensach. Termin common law w prawie angielskim odnosi się również do prawa tworzonego w Anglii od XII w. opartego na zwyczaju

1 P. Mikuli, Zasada podziału władz a ustrój brytyjski, Warszawa 2006. Zob. też idem, Sadownictwo w Zjednoczonym Królestwie. Wybrane zagadnienia ustrojowe, Kraków 2019; J. Szymanek, T. Wieciech, System konstytucyjny Zjednoczonego Królestwa Wielkiej Brytanii i Irlandii Pótnocnej, Warszawa 2019.

2 Tematowi systemu common law zostało poświęcone słynne dzieło autorstwa sędziego Williama Blackstone'a Commentaries on the laws of England, Oxford 1765. 
i precedensie, które przeciwstawia się administrowanemu przez Lorda Kanclerza (ang. Lord High Chancellor of Great Britain) sądownictwu słuszności (ang. equity). W ramach tego systemu sędzia korzysta nie z precedensów, ale z zasady słuszności i sprawiedliwości. Brytyjski system prawny ewoluował, opierając się jednak na swoich historycznych korzeniach. W wyniku uwarunkowań historycznych sądownictwo w Wielkiej Brytanii charakteryzuje się skomplikowaną strukturą, opisaną poniżej.

\section{Ustrój konstytucyjny Wielkiej Brytanii}

Tym, co odróżnia system konstytucyjny Wielkiej Brytanii od innych współczesnych krajów, jest brak konstytucji w sensie formalnym, czyli konkretnego skodyfikowanego aktu prawnego uchwalonego przy zachowaniu określonej nadzwyczajnej procedury. Konstytucja Wielkiej Brytanii istnieje jednak w sensie materialnym. Określa się ją mianem niepisanej (ang. unwritten) konstytucji. Używa się też sformułowania nieskodyfikowanej (ang. uncodified) konstytucji z uwagi na fakt, że część norm konstytucyjnych jest wywodzona z ustaw oraz z orzecznictwa sądów. Konstytucja Wielkiej Brytanii składa się z rozmaitych źródeł prawa, w tym prawa uchwalanego przez parlament, prawa precedensowego i konwenansów konstytucyjnych (ang. conventions). Konwenanse konstytucyjne to polityczne zwyczaje o nadzwyczajnym statusie, które ustalają m.in. prace parlamentu. Konwenanse nie są spisane, ale są bardzo istotne z politycznego punktu widzenia. Konwenansem konstytucyjnym jest przykładowo urząd premiera. Najważniejsze dokumenty konstytucyjne to Magna Carta (1215), The Provisions of Oxford (1258), The Petition of Right (1628), The Bill of Rights (1689) oraz The Act of Settlement (1701), w którym ustalono zasadę niezależności sędziów, The Parliament Acts (1911-1949), The Representation of the People Acts (1918), oraz The Human Rights Act (1998).

Jedną z najbardziej charakterystycznych cech ustroju Wielkiej Brytanii jest suwerenność parlamentu. Sądy nie mogą więc tak jak w innych krajach interpretować prawa wydanego przez parlament pod względem zgodności z konstytucją, bo jest ona nieskodyfikowana. Sądy mogą jedynie interpretować ustawy. 
Ze względów historycznych w Wielkiej Brytanii nie ma jednolitego sądownictwa tak jak w innych krajach. W okresie anglosaskim sądownictwo składało się z dwóch elementów: lokalnego i królewskiego. Sądowi królewskiemu (ang. Curia Regis) przewodniczył sam król, a sądom lokalnym przewodniczył lord lub jeden z jego zarządców. Sędziowie stopniowo uzyskiwali niezależność od monarchy i rządu ${ }^{3}$. Z grupy urzędników sądowych, którzy mieli szczególne doświadczenie w doradzaniu królowi w rozwiązywaniu sporów rozwinęła się instytucja justices in eyre. Sędziowie ci posiadali jurysdykcję zarówno administracyjną, jak i sądową. Zgodnie z deklaracją z Clarendon wydaną w 1166 r. sędziowie, którzy nie zasiadali w wyłonionym z Curia Regis Sądzie Ławy Królewskiej (ang. Court of King's Bench), podróżowali po kraju, wydając wyroki. Na podstawie tych wyroków wiele zwyczajów lokalnych zostało zastąpionych prawem wspólnym dla wszystkich (ang. common law). System polegający na podróżowaniu sędziów po kraju przetrwał do $1971 \mathrm{r}$.

W przeszłości sędziowie wydawali wyroki tak, aby przypodobać się królowi. Korupcja sędziów była w Anglii powszechna. Aby jej zapobiec, w XIII w. podniesiono pensje sędziów, co miało umożliwić im większą niezależność finansową. Osoby niezadowolone z wyroku mogły się odwołać do króla, a w późniejszym okresie do Lorda Kanclerza (ang. Lord High Chancellor of Great Britain). Na mocy Judicature Act wydanym w 1873 r. ustanowiono Sąd Wysoki (ang. High Court) oraz Sąd Apelacyjny (ang. Court of Appeal), do którego można było kierować sprawy cywilne. Apelacja od spraw karnych została umożliwiona dopiero w 1907 r., kiedy na mocy Criminal Appeal Act uchwalono Sąd Apelacyjny ds. Karnych (ang. Court of Criminal Appeal).

Aktami prawnymi relewantnymi dla oceny statusu sędziego w Wielkiej Brytanii są: Tribunals, Courts and Enforcement Act (2007), Courts and Legal Services Act (1990), Judicial Pensions and Retirement Act (1993) i Courts Act (2003). Najistotniejszym aktem prawnym dla oceny statusu sędziego jest jednak The Constitutional Reform Act ${ }^{4}$, uchwalony 24 marca $2005 \mathrm{r}$.

3 J. Hodgson (ed.), The English legal heritage, London 1979.

4 Długi tytuł tej ustawy brzmi: An Act to make provision for modifying the office of Lord Chancellor, and to make provision relating to the functions of that office; to establish a Supreme Court of the United Kingdom, and to abolish the appellate jurisdiction of the 
W ustawie tej podjęto szereg reform istotnych dla brytyjskiego konstytucjonalizmu. Zreformowano urząd Lorda Kanclerza tak, aby rozdzielić władzę wykonawczą od sądowniczej ${ }^{5}$. Lord Kanclerz utracił swoje sądowe uprawnienia na rzecz Lorda Najwyższego Sędziego (ang. Lord Chief Justice), który stanął na czele brytyjskiego sądownictwa. Urząd ten, powstały w 1875 r., wywodzi się z urzędu najwyższego sędziego Sądu Ławy Królewskiej. Od czasu utracenia uprawnień sądowych przez Lorda Kanclerza, sądownictwo stało się w pełni niezależne od rządu, rząd stracił wpływ na rozstrzygnięcia sądowe ${ }^{6}$.

Inną ważną zmianą wprowadzoną przez tę ustawę było utworzenie niezależnej Komisji ds. Nominacji Sędziowskich (ang. Judicial Appointments Commission), której podlega wybór kandydatów na sędziów w Anglii i Walii, powoływanych przez Sekretarza Stanu ds. Sprawiedliwości (ang. Secretary of State for Justice). Działania Komisji, uregulowane w akcie Judicial Appointments Commission Regulations z 2013 r., mają na celu zapewnienie, że najważniejszym kryterium mianowania są przesłanki merytoryczne, a system mianowania sędziów jest otwarty i przejrzysty. Nad przejrzystością procesu mianowania czuwa również Rzecznik ds. Nominacji i Postępowania Sądowego (ang. Judicial Appointments and Conduct Ombudsman), który jest odpowiedzialny za rozpatrywanie skarg i wydawanie zaleceń dotyczących procesu mianowania sędziów, a także skarg na sędziów składanych na podstawie Constitutional Reform Act z 2005 r. W środowisku akademickim uznaje się, że istnienie Komisji i Rzecznika jest dowodem na to, iż możliwe jest pogodzenie konceptu niezależności sędziów z ponoszeniem przez nich odpowiedzialności ${ }^{7}$.

House of Lords; to make provision about the jurisdiction of the Judicial Committee of the Privy Council and the judicial functions of the President of the Council; to make other provision about the judiciary, their appointment and discipline; and for connected purposes. Tekst ustawy dostępny jest na stronie internetowej: http://www.legislation.gov.uk/ ukpga/2005/4/contents (dostęp: 15.03.2019).

5 P. Mikuli, Separation of powers, [w:] R. Grote, F. Lachenmann, R. Wolfrum (eds.), Max Planck encyclopedia of comparative constitutional law, Oxford 2018.

6 G. Jones, Should judges be politicians: The English experience, „Indiana Law Journal” 1982, nr 57 (2), s. 211-233.

7 A. Le Sueur. Developing mechanisms for judicial accountability in the UK, „Legal Studies" 2004, nr 24 (1-2), s. 73-98. 
Na mocy The Constitutional Reform Act z 2005 r. (c 4) powołano również Sąd Najwyższy Zjednoczonego Królestwa (ang. Supreme Court of the United Kingdom), ustalono ilość sędziów w tym sądzie (część 3), sposób mianowania sędziów, a także kwestie takie jak warunki ich zatrudnienia, dodatki i emerytura (sekcje 26-37).

Sąd Najwyższy jest ostateczną instancją dla większości spraw. Wyjątkiem są szkockie sprawy karne, gdzie ostateczną instancją pozostaje High Court of Judiciary. Ze względów historycznych system sądowniczy w Wielkiej Brytanii jest skomplikowany i obejmuje oprócz sądów również system trybunałów. Współcześnie istnieją trzy osobne systemy sądownicze: dla Anglii i Walii, dla Szkocji i dla Irlandii Północnej. Sądy występują głównie w Anglii i Walii, a trybunały w Anglii, Walii, Irlandii Północnej i Szkocji. Każdy z sądów rozstrzyga inny rodzaj spraw. Wszystkie sprawy karne są rozpatrywane w pierwszej instancji przez sądy grodzkie (ang. magistrates' courts) lub Sąd Koronny (ang. Crown Court). Ten ostatni zajmuje się często poważniejszymi sprawami karnymi. Sąd grodzki może przekazać sprawę do rozpatrzenia przez Sąd Koronny. Apelacje w sprawach karnych są przekazywane do Sądu Wysokiego, skąd można odwoływać się do Sądu Apelacyjnego, a następnie do Sądu Najwyższego. Sprawy cywilne z kolei w pierwszej instancji są rozpatrywane przez sądy grodzkie lub sądy okręgowe (ang. county courts). Podobnie jak w przypadku spraw karnych, apelacje można składać do Sądu Wysokiego, a stamtąd do Sądu Apelacyjnego oraz Sądu Najwyższego.

System trybunałów ma osobną strukturę. Składa się z trybunałów pierwszej instancji (ang. First-tier Tribunals) oraz trybunałów wyższej instancji (ang. Upper Tribunals). Obie instancje trybunałów są podzielone na izby. Trybunał pierwszej instancji ma siedem takich izb, a trybunał wyższej instancji - cztery. Oprócz trybunałów pierwszej i wyższej instancji istnieją, poza tym systemem, inne trybunały, np. Trybunały ds. Prawa Pracy (ang. Employment Tribunal). Apelacje z tych trybunałów można składać do Trybunałów Apelacyjnych ds. Prawa Pracy (ang. Employment Appeals Tribunal). Odwołanie od rozstrzygnięć Trybunałów Wyższej Instancji i Trybunałów Apelacyjnych ds. Prawa Pracy można składać do Sądu Apelacyjnego. 
W panelach orzekających trybunałów mogą zasiadać osoby nieposiadające kwalifikacji prawniczych, ale legitymujące się wiedzą specjalistyczną w dziedzinie, w której toczy się postępowanie, np. lekarze, fizjoterapeuci czy pracownicy socjalni ${ }^{8}$. Osoby te nie zakładają togi i peruki podczas pełnienia funkcji sędziowskich. Celem włączenia do trybunałów osób nieposiadających wiedzy prawniczej jest zapewnienie sprawiedliwego procesu. Osoby takie mają stosunkowo duży wpływ na rozstrzygnięcia sądowe w Wielkiej Brytanii'.

\section{Otoczenie społeczno-polityczne wymiaru sprawiedliwości}

Brytyjski wymiar sprawiedliwości zmaga się z problemami związanymi z sytuacją społeczno-polityczną. Przestępczość w Wielkiej Brytanii jest jedną z wyższych w Europie ${ }^{10}$. W ostatnich latach odnotowuje się coraz wyższy odsetek ataków przemocy z użyciem noża lub innego ostrego przedmiotu, a liczba zabójstw wzrosła po długotrwałym wcześniejszym spadku ${ }^{11}$. Najwięcej przestępstw w Wielkiej Brytanii wśród mniejszości narodowych dokonali Polacy, stanowiąc w 2018 r. 9\% wszystkich osadzonych obcokrajowców ${ }^{12}$. Można to wyjaśnić faktem, iż to Polacy są właśnie największą mniejszością narodową w Wielkiej Brytanii, która od lat obok Niemiec pozostaje nadal najpopularniejszym kierunkiem emigracji Polaków.

Pomimo wysokiego poziomu przestępczości, korupcja wśród sędziów brytyjskich jest zjawiskiem rzadkim ${ }^{13}$. Sądownictwo jest postrzegane jako

8 Tribunals, Courts and Enforcement Act 2007, schedule 2, $\mathbb{\$} 2(1)$.

9 C. Foster, Will clinical guidelines replace judges?, „Medicine and Law” 2006, nr 25, s. 585-591.

10 N. Cowen, N. Williams, Civitas crime briefing, comparisons of crime in OECD countries, CIVITAS Institute for the Study of Civil Society, 2012, [online:] http://www.civitas. org.uk/content/files/crime_stats_oecdjan2012.pdf (dostęp: 15.05.2019).

11 Office for National Statistics, Crime in England and Wales: year ending September 2018 , 2019, [online:] https://www.ons.gov.uk/peoplepopulationandcommunity/crimeandjustice/ bulletins/crimeinenglandandwales/yearendingseptember2018\#overview-of-crime.

12 G. Sturge, UK prison population statistics, „Briefing Paper” 2018, nr CBP-04334.

13 World Economic Forum, The global competitiveness report 2017-2018, [online:] http://reports.weforum.org/global-competitiveness-index-2017-2018/countryeconomy-profiles/\#economy=GBR; Bureau of Economic and Business Affairs, Investment climate 
niezależne, otwarte i godne zaufania ${ }^{14}$. System sądowy jest określany jako wydajny, a zasada państwa prawa jest przestrzegana ${ }^{15}$. Przedsiębiorstwa mają zaufanie co do tego, że system sądownictwa jest niezależny i są usatysfakcjonowane sposobem, w jaki rozwiązywane są konflikty prawne ${ }^{16}$.

Rada Europy chwaliła sędziów i prokuratorów brytyjskich za skuteczne zapobieganie korupcji ${ }^{17}$, a rząd brytyjski aktywnie jej przeciwdziała, rozpowszechniając materiały antykorupcyjne wśród sędziów ${ }^{18}$. Sędziowie uczestniczą również w treningu dotyczącym etyki zawodu sędziego, w ramach którego zapoznają się z nagraniami z sali sądowej i spoza, w których poruszane są dylematy etyczne ${ }^{19}$.

Mimo rzadko występującej korupcji i wysokiego prestiżu, jakim cieszy się urząd sędziego w społeczeństwie, sędziowie postrzegani są jednak jako osoby odseparowane od reszty społeczeństwa i niemające doświadczeń i znajomości problemów tzw. przeciętnego obywatela ${ }^{20}$. Brak różnorodności i klasowość społeczeństwa brytyjskiego jest problemem wielu profesji, ale zwłaszcza w przypadku sędziów ten problem jest wyjątkowo rażący.

Brytyjskie społeczeństwo jest społeczeństwem klasowym, w którym klasa społeczna ma silny wpływ na status społeczny ${ }^{21}$. Poszczególne klasy społeczne zazwyczaj mieszkają w osobnych dzielnicach. Bezpieczeństwo, poziom opieki zdrowotnej, szkolnictwa, a także innych usług państwowych zależy często od miejsca zamieszkania ${ }^{22}$. Zróżnicowany dostęp do usług określa się mianem „loterii kodów pocztowych” (ang. postcode lottery).

statements for 2018, [online:] https://www.state.gov/e/eb/rls/othr/ics/investmentclimatestatements/index.htm\#wrapper (dostęp: 15.03.2019).

14 Bureau of Economic and Business Affairs, Investment climate statements for $2018 \ldots$

15 Ibidem.

16 World Economic Forum, The global competitiveness report 2017-2018...

17 Council of Europe, Group of States against Corruption, Evaluation report. Preventing corruption and promoting integrity in central governments (top executive functions) and law enforcement agencies, 2018, [online:] https://rm.coe.int/fifth-evaluation-round-preventing-corruption-and-promoting-integrity-i/168088ea4c (dostęp: 15.03.2019).

18 Ibidem.

19 Ibidem.

20 M. McConville, L. Marsh, Criminal judges. Legitimacy, courts and state-induced guilty legitimacy, courts and state-induced guilty pleas in Britain, Cheltenham 2014.

${ }^{21}$ T.W. Chan, J. Goldthorpe, Is there a status order in contemporary British society?, „European Sociological Review” 2004, nr 20 (5), s. 383-401.

${ }^{22}$ Zob. np. H. Mooney, Quality of stroke care varies widely across England, „British Medical Journal" 2010, nr 340:c1816. 
Poszczególne klasy społeczne różnią się nie tylko miejscem zamieszkania i zasobami finansowymi, ale także sposobem, w jaki spędzają wolny czas, posiadanym hobby ${ }^{23}$, używanym słownictwem, a nawet akcentem ${ }^{24}$.

Zgodnie z raportem rządowym wydanym przez Social Mobility and Child Poverty Commission, zawód sędziego jest najbardziej elitarnym zawodem w Wielkiej Brytanii ${ }^{25}$. Kapitał kulturowy odgrywa tu istotną rolę. Ponad 70\% sędziów uczęszczało do szkól prywatnych, a odsetek ten w przypadku społeczeństwa brytyjskiego wynosi $7 \%{ }^{26}$. Co więcej, jeden na siedmiu sędziów (14\%) uczęszczał do jednej z pięciu następujących szkół: Eton, Westminster, Radley, Charterhouse i St Paul's Boys ${ }^{27}$. Cztery z tych szkół kształcą wyłącznie chłopców. Po otrzymaniu prestiżowego wykształcenia większość późniejszych sędziów (75\%) wybiera jeden z dwóch najbardziej pożądanych uniwersytetów w Anglii - Cambridge lub Oxford. W przypadku przedstawicieli innych zawodów odsetek osób uczęszczających na jedną z tych dwóch uczelni wynosi $1 \%{ }^{28}$.

Warto wziąć pod uwagę, że egzaminy wstępne na te uniwersytety obejmują rozmowę kwalifikacyjną, podczas której czynniki takie jak np. posiadany akcent mogą, świadomie lub podświadomie, odgrywać rolę przy przyjęciu na te prestiżowe studia. Rozmowa kwalifikacyjna jest na tych uczelniach bardziej brana pod uwagę niż w innych krajach, w których nacisk położony jest głównie na anonimowe, często standaryzowane, egzaminy z wiedzy merytorycznej. Jak odnotowuje jednak Penny Darbyshire, brak różnorodności jest problemem nie tyle brytyjskiego sądownictwa, co szkolnictwa oraz historycznie uwarunkowanych kulturowych

\footnotetext{
${ }^{23}$ B. Le Roux et al., Class and cultural division in the UK, „Sociology” 2008, $\mathrm{nr} 42$, S. $1049-1071$.

24 Akcentem, który uznaje się za akcent osób o wysokim statusie społecznym i wskazującym na posiadanie dobrego wyksztalcenia jest tzw. received pronunciation, zob. T. McArthur, The Oxford guide to world English, Oxford 2002.

25 Social Mobility and Child Poverty Commission, Elitist Britain?, [online:] https://assets. publishing.service.gov.uk/government/uploads/system/uploads/attachment_data/file/ 347915/Elitist_Britain___Final.pdf (dostęp: 15.03.2019).

26 Ibidem.

27 Ibidem.

28 Ibidem.
} 
postaw wobec edukacjii ${ }^{29}$. Ponadto, jak dalej argumentuje Darbyshire, przewaga absolwentów prywatnych szkól oraz Oxbridge ${ }^{30}$ występuje nie tylko w sądownictwie, ale również pośród polityków, pracowników służby cywilnej, w prywatnych przedsiębiorstwach, a nawet wśród najbardziej popularnych aktorów komediowych ${ }^{31}$.

Brak różnorodności jest jednak widoczny w statystykach sądowych. Kobiety stanowią jedynie $24 \%$ sędziów w sądach i $46 \%$ w trybunałach; w sądach apelacyjnych i sądach wyższych odsetek kobiet wynosi $24 \%$, a w trybunałach wyższej instancji $-41 \%^{32}$. Niektórzy argumentują, iż wynika to z głęboko zakorzenionego wizerunku sędziego w społeczeństwie brytyjskim jako mężczyzny oraz dyskryminacji i wyłączenia kobiet z życia publicznego ${ }^{33}$. Sally J. Kenney z kolei winę za brak kobiet w sądownictwie przypisała m.in. brytyjskim środowiskom feministycznym, które nie walczyły dostatecznie o miejsca dla kobiet w sądownictwie, gdyż funkcje w wyższym sądownictwie brytyjskim nie są dostatecznie eksponowane politycznie ${ }^{34}$.

Osoby czarnoskóre, pochodzenia azjatyckiego i mniejszości etniczne, określane w Wielkiej Brytanii jako BAME (ang. black, Asian and minority ethnic) również nie mają należytej reprezentacji - ok. 8\% sędziów identyfikuje się jako BAME ( $7 \%$ w sądach i 11\% w trybunałach) ${ }^{35}$. Peter Herbert, przewodniczący Society of Black Lawyers, skomentował: Statystyki pokazuja, że różnorodność rasowa w sqdownictwie po prostu nie postępuje

${ }^{29}$ P. Darbyshire, Where do English and Welsh judges come from?, "Cambridge Law Journal" 2007, nr 66 (2), s. 365-388.

30 Tą wspólną nazwą określa się uczelnie Cambridge i Oxford.

31 P. Darbyshire, op. cit., s. 365-388.

32 Lord Chief Justice of England and Wales \& Senior President of Tribunals, Judicial diversity statistics 2018, [online:] https://www.judiciary.uk/wp-content/uploads/2018/07/ judicial-diversity-statistics-2018-1.pdf (dostęp: 15.03.2019).

33 D. Feenan, Women judges. Gendering judging, justifying diversity, „Journal of Law and Society" 2008, nr 35 (4), s. 490-519.

34 S.J. Kenney, Gender on the agenda. How the paucity of women judges became an issue, „Journal of Politics” 2008, nr 70 (3), s. 717-735.

35 Ibidem. 
wystarczająco szybko. Kiedy królewska ceremonia ślubna wykazała większq różnorodność rasowa niż nasz system sprawiedliwości, coś jest nie tak ${ }^{36}$.

Funkcjonowanie systemu mianowania sędziów jest również przedmiotem dyskusji w środowisku sędziowskim, gdyż jeden na czterech sędziów uważa, że niektórzy kandydaci na te stanowiska zostali wybrani lub otrzymali awans na podstawie innych czynników niż doświadczenie lub przesłanki merytoryczne ${ }^{37}$.

\section{Podstawy prawne statusu sędziego}

\subsection{Wymogi wobec kandydatów na sędziów}

Nad wyborem kandydatów na sędziów czuwa, jak to zostało wcześniej wspomniane, Komisja ds. Nominacji Sędziowskich. Komisja ta składa się z czternastu Komisarzy, z których siedmiu musi być sędziami, pięciu nie może być prawnikami, a dwóch musi być prawnikami ${ }^{38}$. Spośród siedmiu Komisarzy, którzy są sędziami, pierwszy to Lord Justice of Appeal, drugi to sędzia Sądu Wysokiego, trzeci to sędzia senior zasiadający w trybunale, czwarty to sędzia okręgowy (ang. circuit judge), piąty to sędzia sądu rejonowego (ang. district judge), szósty to sędzia sądu pracy (ang. employment judge) lub sędzia w trybunale pierwszej instancji (ang. judge of the First-tier Tribunal) ${ }^{39}$. Ostatnim Komisarzem jest sędzia, który nie posiada kwalifikacji prawniczych ${ }^{40}$. Jest to taki sędzia, który nigdy nie praktykował prawa ani nie był zatrudniony jako prawnik ${ }^{41}$.

Komisja wybiera sędziów, opierając się na kryteriach, z których podstawowymi są ich kwalifikacje zawodowe, doświadczenie zawodowe,

\footnotetext{
${ }^{36}$ K. Talsania, Majority of lawyers recommended to be judges went to state school, [online:] https://theboar.org/2018/o6/majority-lawyers-judges-state-school/ (dostęp: 15.03.2019).

${ }^{37}$ European Network of Councils for the Judiciary, Independence, accountability and quality of the judiciary performance indicators 2017, [online:] https://www.encj.eu/images/ stories/pdf/workinggroups/independence/encj_report_ia_ga_adopted_ga_13_6.pdf.

38 Judicial Appointments Commission Regulations 2013, $\mathbb{4}$.

39 Ibidem.

40 Ibidem.

$41 \quad$ Ibidem, $\$ 6$.
} 
obywatelstwo, wiek oraz posiadanie dobrego charakteru. Doświadczenie zawodowe jest istotnym kryterium, gdyż sędziowie przechodzą jedynie bardzo ograniczone szkolenie zawodowe. W Wielkiej Brytanii istnieje domniemanie, że wcześniejsze doświadczenie zawodowe jest wystarczające do podjęcia praktyki sądowej ${ }^{42}$.

Kandydaci powinni posiadać pięć lub siedem lat doświadczenia zawodowego zdobytego po ukończeniu studiów prawniczych. Nie ma znaczenia, czy była to praca płatna czy nieodpłatna, na pełen etat czy na część etatu ${ }^{43}$. Praca ta jednak musi obejmować minimum 20\% czasu pracy w ciągu roku i może być wykonywania na terenie Wielkiej Brytanii lub w innym $\mathrm{kraju}^{44}$. Okres doświadczenia zawodowego jest mierzony przez komisję od momentu rozpoczęcia pracy zawodowej. Za tę datę można przyjąć np. datę ukończenia aplikacji adwokackiej lub innej aplikacji. Ostatnim dniem tego okresu jest data przesłania przez komisję rekomendacji kandydata na sędziego.

Jako doświadczenie zawodowe uznaje się pełnienie funkcji sędziego w sądzie lub trybunale; pełnienie funkcji arbitra; wykonywanie zawodu prawnika; doradztwo prawne (również w ramach wdrażania prawa); asystowanie osobom, które dokonują rozstrzygnięć spraw związanych z prawem; pełnienie funkcji mediatora w sprawach, które mogą być przedmiotem procesu sądowego; wykonywanie projektów dokumentów, które mają wpływ na prawa i obowiązki; wykładanie prawa lub prowadzenie badań naukowych z dziedziny prawa oraz jakakolwiek inna aktywność zawodowa podobna, w opinii odpowiedniego organu, do wymienionych powyżej ${ }^{45}$.

Kryterium posiadania kwalifikacji zawodowych spełniają następujące osoby:

- barristers,

- solicitors,

- chartered legal executives (jednak wyłącznie w sądach rejonowych, trybunałach pierwszej instancji, w sądzie pracy i jako Adjudicator),

- prawnicy zatrudnieni przez rząd i prokuratorzy,

42 C. Munro, M. Wasik, Sentencing, judicial discretion and judicial training, London 1992.

43 Tribunals, Courts and Enforcement Act 2007, sec. 52.

44 Ibidem.

45 Ibidem. 
- nauczyciele akademiccy,

- patent and trade mark attorneys, którzy mogą ubiegać się o stanowisko przewodniczącego w Copyright Tribunal, zastępcy przewodniczącego w tym trybunale lub sędziego apelacyjnego rozstrzygającego na podstawie Trade Marks Act 1994.

Kandydaci na sędziów nieposiadający kwalifikacji prawniczych powinni posiadać odpowiednie kompetencje, w zależności od stanowiska sędziowskiego, o które się ubiegają. Wymagania w tym zakresie zazwyczaj są umieszczone w ogłoszeniu o konkursie na dane stanowisko. Powinni spełniać również warunki w zakresie wieku i obywatelstwa, podobnie jak inni kandydaci na sędziów.

Kandydaci na sędziów muszą posiadać obywatelstwo Wielkiej Brytanii, obywatelstwo Wspólnoty Narodów (ang. commonwealth citizenship) ${ }^{46}$ lub obywatelstwo Republiki Irlandii. Obywatele krajów Unii Europejskiej nie mogą zostać sędziami w Wielkiej Brytanii. Ponadto niektóre stanowiska sędziowskie mogą być dostępne wyłącznie dla osób posiadających kwalifikacje uzyskane w danym kraju Wielkiej Brytanii.

Nie ma wymogu minimalnego wieku dla kandydatów na sędziów, istnieje jednak górna granica, ok. 65-67 lat, gdyż sędziowie brytyjscy przechodzą w stan spoczynku w wieku 70 lat. Komisja decyduje o górnej granicy wieku, biorąc pod uwagę konkretne stanowisko sędziowskie.

Oprócz tych wymogów sędziowie również, na podstawie Constitutional Reform Act 2005, powinni spełnić warunek posiadania dobrego charakteru $^{47}$. Komisja, dokonując oceny etycznej kandydata, bierze pod uwagę deklarację wypełnioną przez kandydata oraz niezależnie ocenia tę deklarację, sprawdzając ją z danymi różnych organizacji, włączając brytyjski Rejestr Karny (ang. ACRO Criminal Records Office), urzędy skarbowe, rady adwokackie i inne. Kandydat na sędziego powinien ujawnić wszystkie postępowania karne i dyscyplinarne, jakie toczyły się przeciwko niemu. Komisja bierze też pod uwagę nadużycia w mediach społecznościowych i na stronach internetowych, do których należą wypowiedzi

\footnotetext{
46 Lista krajów, których obywatele są obywatelami Wspólnoty Narodów znajduje się w British Nationality Act 1981, schedule 3.

47 Constitutional Reform Act 2005, section 63(3).
} 
dyskryminujące osoby chronione przez Equality Act. Również osoby, które nie zapłaciły podatków lub są niewypłacalne, mogą nie zostać rekomendowane przez Komisję na stanowisko sędziowskie. Komisja bierze jednak pod uwagę okoliczności łagodzące każdej sprawy, np. to, czy dług został zredukowany.

\subsection{Procedura powoływania sędziów}

Procedura wyboru na stanowiska sędziowskie rozpoczyna się w momencie upływu terminu do zgłoszenia kandydatów. Podczas oceny kandydatów na sędziów bierze się pod uwagę, zgodnie z Constitutional Reform Act 2005, głównie przesłanki merytoryczne oraz dobry charakter ${ }^{48}$. Ustawa ta zachęca również do dokonywania wyboru pośród kandydatów z uwzględnieniem zasady różnorodności ${ }^{49}$. Zasada ta nie może jednak być traktowana priorytetowo względem oceny merytorycznej kandydatów, jak i oceny ich dobrego charakteru ${ }^{50}$.

W pierwszej fazie oceny kandydatów Komisja Rekrutacyjna dokonuje analizy ich kwestionariuszy, rekomendacji oraz sprawdza, czy kandydaci spełniają wymogi niezbędne do wykonywania zawodu sędziego. Następnie na wiele stanowisk sędziowskich przeprowadza się test wśród kandydatów w celu oceny zdolności kandydata do pełnienia roli sędziego, analizowania informacji, identyfikowania problemów i odpowiedniego stosowania prawa $^{51}$. Kandydaci otrzymują niezbędne materiały i podstawowe informacje na temat testu - jak będzie wyglądał i jak się do niego przygotować. Każdy test jest dostosowany do konkretnego stanowiska i jest opracowywany przez doświadczonych sędziów z odpowiedniej jurysdykcji.

Komisja ds. Nominacji Sędziowskich poważnie podchodzi do kwestii praw religijnych i stara się, w miarę możliwości, unikać wyznaczania terminu testu w dni, w które wypadają święta religijne. Niestety, nie jest

48 Ibidem, section 63.

49 Ibidem, section 64 .

50 Ibidem.

51 Komisja ds. Nominacji Sędziowskich, Qualifying tests, [online:] https://www.judicialappointments.gov.uk/qualifying-tests (dostęp: 15.03.2019). 
to całkowicie możliwe do zrealizowania, aby testy były przeprowadzane zawsze w terminach, w których nie wypadają żądne święta religijne, gdyż dokładnych dat niektórych świąt nie można ustalić z wielomiesięcznym wyprzedzeniem (w czasie, kiedy planuje się test ${ }^{52}$. Jednak nawet w sytuacji, kiedy święta religijne obchodzone przez któregoś z kandydatów kolidują z terminem testu, komisja organizuje dla niego lub niej test w późniejszym terminie, najczęściej ok. tydzień później ${ }^{53}$. Testy nie są również planowane na dni wolne od pracy i szkoły ${ }^{54}$.

Test jest przeprowadzany online, gdyż w ten sposób kandydaci na sędziów mogą do niego podejść w dogodnym dla nich czasie i lokalizacji, a proces selekcji jest szybszy i bardziej ekonomiczny ${ }^{55}$. Testy wielokrotnego wyboru są oceniane automatycznie, a testy pisemne są oceniane przez sędziów z danej jurysdykcji ${ }^{56}$. Sposób oceny testów pisemnych jest moderowany, aby zapewnić spójność ocen ${ }^{57}$. Indywidualne oceny kandydatów nie są podawane, zamiast tego publikuje się raport na temat wyników wszystkich kandydatów ${ }^{58}$. Liczbę osób zaproszonych do kolejnego etapu rekrutacji ustala się na podstawie zdobytych wyników z testu ${ }^{59}$.

W kolejnym etapie z wybranymi kandydatami przeprowadza się rozmowę telefoniczną. Kandydaci zostają z wyprzedzeniem poinformowani, czego ta rozmowa będzie dotyczyć, jej tematem może być np. analiza wyroku sądu ${ }^{60}$. Kandydaci mogą być również oceniani na podstawie znajomości języka. Jeżeli np. znajomość języka walijskiego była wymagana od kandydatów na dane stanowisko sędziowskie, ta znajomość będzie oceniana właśnie podczas rozmowy telefonicznej ${ }^{61}$.

\footnotetext{
52 Ibidem.

3 Ibidem.

4 Ibidem.

5 Ibidem.

56 Ibidem.

57 Ibidem.

58 Ibidem.

59 Ibidem.

60 Komisja ds. Nominacji Sędziowskich, Telephone assessments, [online:] https://www. judicialappointments.gov.uk/telephone-assessments (dostęp: 15.03.2019).

61 Ibidem.
} 
Po rozmowie telefonicznej wybrani kandydaci zostają zaproszeni na rozmowę kwalifikacyjną ${ }^{62}$. Na tej rozmowie kandydaci na sędziów mogą zostać poproszeni o odpowiedź na pytanie sytuacyjne dotyczące scenariuszy, z którymi można się zetknąć na sali sądowej, a także o wzięcie udziału w odgrywaniu ról, symulacji lub przedstawienie prezentacji na konkretny temat $^{63}$. Informacje na temat tego, co dokładnie będzie wymagane od kandydatów, są udzielane wcześniej ${ }^{64}$. Podczas odgrywania ról i symulacji kandydaci wcielają się w rolę sędziego i odgrywają ją na podstawie scenariusza, z udziałem profesjonalnych aktorów grających inne role ${ }^{65}$. Ten typ zadania wykorzystywany jest szczególnie w przypadku kandydatów, którzy nie wykonywali jeszcze zawodu sędziego ${ }^{66}$ Prezentacje z kolei odbywają się przy rekrutacji na stanowiska wyższego szczebla, zwykle takie, które wymagają umiejętności przywódczych i zarządzania ${ }^{67}$.

Panele rekrutacyjne zazwyczaj składają się z trzech członków, w tym z: przewodniczącego, członka sądu i niezależnego członka. Podczas niektórych rozmów rekrutacyjnych obecni są obserwatorzy, którzy przyglądają się panelowi, a nie kandydatowi ${ }^{68}$. Komisja nie zwraca kandydatom wydatków poniesionych w dniu rozmowy kwalifikacyjnej, wyjątek jest przewidziany wyłącznie dla osoby niepełnosprawnej ${ }^{69}$.

Zgodnie z Judicial Appointment Regulations 2013 Komisja przeprowadza następnie konsultacje z osobą, która sprawowała urząd, o który ubiegają się kandydaci, lub z osobą o innym odpowiednim doświadczeniu. Konsultacja może się nie odbyć, gdy wyrazi na to zgodę Przewodniczący Komisji ds. Nominacji Sędziowskich, Lord Kanclerz, Lord Najwyższy

${ }^{62}$ Komisja ds. Nominacji Sędziowskich, Selection Day, [online:] https://www.judicialappointments.gov.uk/selection-day (dostęp: 15.03.2019).

63 Ibidem.

${ }^{64}$ Ibidem.

65 Ibidem.

${ }^{66}$ Ibidem.

67 Ibidem.

68 Ibidem.

69 Ibidem. 
Sędzia lub Senior Prezes Trybunałów ${ }^{70}$. W przypadku kandydatów na stanowiska do Sądu Wysokiego konsultantem jest Lord Najwyższy Sędzia ${ }^{71}$.

Komisja ds. Nominacji Sędziowskich konsultuje również dobry charakter kandydatów z organami zewnętrznymi, np. może skonsultować z Office for Judicial Complaints, czy na kandydata nie wpłynęły skargi ${ }^{72}$. Komisja następnie rekomenduje kandydatów właściwemu organowi (Lorda Kanclerza, Lorda Najwyższego Sędziego lub Seniora Prezesa Trybunałów) do mianowania ich na stanowisko sędziego. Kandydatom, którym się nie powiodło, Komisja ds. Nominacji Sędziowskich zapewnia udzielenie wyjaśnień $^{73}$.

\subsection{Immunitet sędziowski}

Sędziowie brytyjscy posiadają immunitet sędziowski obejmujący czynności w ramach wykonywanych funkcji sędziowskich. Zasada ta ma swoje źródło w prawie common law, a konkretnie w sprawie Sirros v. Moore [1975] QB 118, w której Lord Denning oświadczył: Bez względu na to, czy sędzia byt $w$ btędzie lub nie posiadat odpowiedniej wiedzy albo kierowat się zazdrościa, nienawiścia, złośliwościa lub byt po prostu nieuprzejmy, nie podlega on oskarżeniu ${ }^{74}$.

Immunitet sędziowski obejmuje oskarżenie przed sądami karnymi oraz bycie pozwanym o zniesławienie odnośnie tego, co sędzia powiedział o stronach procesu lub świadkach ${ }^{75}$.

\footnotetext{
${ }^{70}$ Komisja ds. Nominacji Sędziowskich, Statutory consultation,[online:] https://www. judicialappointments.gov.uk/statutory-consultation (dostęp: 15.03.2019).

71 Ibidem.

72 Ibidem.

${ }^{73}$ Komisja ds. Nominacji Sędziowskich, Feedback reports, [online:] https://www.judicialappointments.gov.uk/feedback-reports (dostęp: 15.03.2019).

${ }^{74}$ Zob. też Hinds v. Liverpool County Court and others, [2008] EWHC 665, $\$ 13$.

75 Crown Proceedings Act 1947, section 2(5); Courts Act 2003, sections 31 i 32.
} 


\subsection{Nieusuwalność}

Sędzia powoływany jest dożywotnio. Uznaje się, że nie będzie on wykonywał już żadnego innego zawodu. Sędzia może być usunięty wyłącznie na skutek ubezwłasnowolnienia lub niegodnego zachowania ${ }^{76}$. Usunięcia dokonuje Lord Kanclerz po konsultacji z Lordem Najwyższym Sędzią ${ }^{77}$.

Koncept nieusuwalności sędziego został wprowadzony w $1701 \mathrm{r}$. w Act of Settlement, w którym wprowadzono mechanizmy formalne chroniące sędziów przed usunięciem ze stanowiska przez władcę, co w tamtych czasach często się zdarzało. Wówczas, zgodnie z Act of Settlement, aby usunąć sędziego seniora, potrzeba było zgody obu izb parlamentu.

\subsection{Niepołączalność i ograniczenia innego typu}

Sędziowie brytyjscy nie mogą angażować się w żadne czynności, które mogą podważać bezstronność sędziowską. Do takich należy praktykowanie jako barrister albo solicitor ${ }^{78}$. Sędziowie nie mogą również pełnić funkcji politycznych ani być dyrektorami przedsiębiorstw. Jeżeli sędzia zostanie nominowany do Parlamentu, Parlamentu Szkocji, Walijskiego Zgromadzenia Narodowego, Zgromadzenia Narodowego Irlandii Północnej lub do Parlamentu Europejskiego powinien złożyć rezygnację ze stanowiska sędziego Lordowi Kanclerzowi. Do 2005 r. sędziowie mogli jednak zasiadać w Izbie Lordów.

\subsection{Uprawnienia socjalne sędziów}

Sędziowie posiadają szereg uprawnień socjalnych oraz stosunkowo wysokie uposażenie, które w zależności od stanowiska sędziowskiego mieści się

\footnotetext{
76 Courts Act 1971, section 17(4).

77 Ibidem.

78 Courts and Legal Services Act 1990, section 75.
} 
między 110000 a 250000 funtów rocznie ${ }^{79}$. Od tych zarobków sędziowie płacą podatek dochodowy na podstawie części 2-7 Income Tax (Earnings and Pensions) Act 2003. Pensja sędziego jest pomniejszana o ten podatek oraz o ubezpieczenie społeczne. Sędziowie uiszczają niższe składki, gdyż pełnią funkcję państwową. W ramach ubezpieczenia społecznego sędziowie są sklasyfikowani jako employed earner, a ich składki jako Class 1. Sędziowie zazwyczaj odchodzą na emeryturę w dniu 70 urodzin ${ }^{80}$. Wówczas nie uiszczają już składek na ubezpieczenie społeczne, nawet w przypadku, gdy kontynuują zatrudnienie.

Sędziowie mają prawo do wynagrodzenia za czas choroby bez ograniczenia czasowego, pod warunkiem, że będą w stanie powrócić jeszcze do pracy. Sędziowie nie otrzymują dodatku za transport z miejsca zamieszkania do sądów, w których pracują, mogą jednak otrzymać taki dodatek $\mathrm{z}$ innych powodów, $\mathrm{np}$. z racji uczestniczenia w seminarium. Sędziowie otrzymują również inne dodatki, np. dodatek relokacyjny jest przyznawany, gdy do zmiany miejsca zamieszkania sędziego doszło na skutek decyzji Lorda Kanclerza albo Lorda Najwyższego Sędziego. Jeżeli sędzia sam zawnioskował o przeniesienie, dodatek taki mu nie przysługuje. Sędziowie mają prawo do urlopu macierzyńskiego, ojcowskiego i związanego z adopcją dziecka. Sędziowie mogą również sprawować swoją funkcję na pół etatu, jednak nawet wtedy nie mogą łączyć tej pracy z wykonywaniem innego zawodu związanego z praktykowaniem prawa.

\subsection{Odpowiedzialność sędziów}

W Wielkiej Brytanii nie ma kodeksu etycznego wykonywania zawodu sędziego. Zamiast tego sędziowie brytyjscy powinni przestrzegać zasad wyrażonych w poradniku Guide to judicial conduct ${ }^{81}$. Poradnik ten nie

\footnotetext{
79 Pensje sędziów w 2018 r. [dane brytyjskiego Ministerstwa Sprawiedliwości], [online:] https://assets.publishing.service.gov.uk/government/uploads/system/uploads/attachment_data/file/756059/judicial-salaries-revised-14-nov-2018.pdf (dostęp: 15.03.2019).

${ }_{80}$ Judicial Pensions and Retirement Act 1993, section 26.

81 Guide to judicial conduct, [online:] https://www.judiciary.uk/wp-content/uploads/ 2016/07/judicial-conduct-v2018-final-2.pdf (dostęp: 15.05.2019).
} 
składa się z przepisów, ale właśnie z zasad, które służą sędziom do oceny etycznej własnego postępowania. Guide to judicial conduct jest oparty na zasadzie odpowiedzialności indywidualnej - każdy sędzia jest indywidualnie odpowiedzialny za podjęcie decyzji, czy dany czyn lub bezczynność są zgodne z etyką wykonywanego zawodu. Naruszenie tego kodeksu może prowadzić do postępowania dyscyplinarnego, a w jego wyniku do tymczasowej lub całkowitej utraty pełnionej funkcji ${ }^{82}$.

Postępowanie dyscyplinarne sędziów jest prowadzone przez Lorda Kanclerza i Lorda Najwyższego Sędziego zgodnie z Częścią 4 Constitutional Reform Act 2005. Lord Kanclerz i Lord Najwyższy Sędzia egzekwują swoją władzę dyscyplinarną względem sędziów przy pomocy specjalnie powołanego do tego celu urzędu Judicial Conduct Investigations Office. Zarówno Lord Kanclerz i Lord Najwyższy Sędzia oraz Judicial Conduct Investigations Office mogą w swojej ocenie czynów i zaniechań sędziów odwoływać się do Guide to judicial conduct, ale mogą też nie brać tego poradnika pod uwagę.

Na mocy Judicial Discipline (Prescribed Procedures) Regulations 2014 skargi na czyny lub zaniechania sędziów składa się do Judicial Conduct Investigations Office ${ }^{83}$. Skargi można składać na następujące stanowiska sędziowskie:

- Deputy District Judge,

- District Judge,

- Master,

- Recorder,

- Coroner/Assistant Coroner,

- Circuit Judge,

- High Court Judge,

- Lord Justice.

Judicial Conduct Investigations Office nie rozpatruje skarg na sędziów pokoju (ang. justice of peace), które powinny być kierowane do komisji powołującej tych sędziów (ang. Local Advisory Committee) ${ }^{84}$. Z kolei

\footnotetext{
82 Judicial Discipline (Prescribed Procedures) Regulations 2014.

83 Ibidem, schedule 6(1).

84 Ibidem, schedule 6(2).
} 
skargi na sędziów trybunałów (ang. tribunal judges) są rozpatrywane przez prezesa danego trybunału ${ }^{85}$.

Nie wszystkie sprawy można kierować do Judicial Conduct Investigations Office. Urząd ten rozpatruje głównie sprawy związane z używaniem rasistowskiego, seksistowskiego lub obraźliwego języka przez sędziów, szczególnie w mediach społecznościowych, używanie stanowiska do osiągania korzyści osobistych czy zaśnięcie podczas rozprawy. Judicial Conduct Investigations Office nie rozpatruje spraw związanych z popełnieniem przez sędziego oszustwa lub przestępstw oraz skarg związanych ze sprawą, w której dany sędzia orzekał lub orzeka. Do tych spraw należą skargi na: kierowanie się uprzedzeniami przy podejmowaniu decyzji, ograniczenie czasu na wypowiedź w stosunku do jednej ze stron, odmowę wysłuchania świadka lub przyjęcia dowodu w sprawie, popełnionego błędu proceduralnego, błędnej analizy przepisów prawa, odmowę prowadzenia korespondencji ze stroną, odmowę przekazania sprawy do innego sędziego lub innego sądu, wysokość przyznanych kosztów lub odszkodowań, przychylniejszą reakcję na dowody jednej ze stron, kwestionowanie wiarygodności lub dowodów jednej ze stron czy krytykę jednej ze stron postępowania.

Panel dyscyplinarny składa się z czterech członków: sędziego lub byłego sędziego o wyższej randze niż sędzia, którego dotyczy postępowanie, sędziego lub byłego sędziego o takiej samej randze jak sędzia, którego dotyczy postepowanie, oraz dwóch innych członków, z których żaden nie jest ani sędzią ani praktykującym prawnikiem ${ }^{86}$. Panelowi przewodniczy sędzia lub były sędzia o wyższej randze niż sędzia, którego dotyczy postępowanie ${ }^{87}$.

Sprawa może zakończyć się oddaleniem skargi lub wymierzeniem kary dyscyplinarnej ${ }^{88}$. Oddalenie skargi może nastąpić na skutek uznania, że sędzia dokonał zarzucanego mu czynu lub zaniechania, ale nie stanowi

\footnotetext{
${ }^{85}$ Ibidem, schedule 6(3).

86 Ibidem, schedule 11.

87 Ibidem.

88 Ibidem, schedule 15(1).
} 
to naruszenia dyscypliny i sprawa może zostać rozwiązana w sposób nieformalny ${ }^{89}$. Wynik postępowania może zostać opublikowany ${ }^{90}$.

Każda ze stron, która nie jest zadowolona z wyniku postępowania dyscyplinarnego, zarówno sędzia, jak i osoba składająca skargę, może zwrócić się o jego rewizję przez rzecznika (ang. Judicial Appointments and Conduct Ombudsman). Rzecznik rozpatruje skargi wyłącznie, jeżeli zostały wcześniej rozpatrzone przez Judicial Conduct Investigations Office, Local Advisory Committee lub prezesa trybunału. Wniosek o apelację należy złożyć w ciągu 28 dni od dnia otrzymania ostatecznej decyzji w pierwszej instancji ${ }^{91}$. Rzecznik może utrzymać decyzję podjętą w pierwszej instancji lub oddalić skargę. Rzecznik może zarekomendować:

- obowiązek przeproszenia strony,

- finansowe zadośćuczynienie dla strony,

- zmiany w procesie składania skargi na sędziego,

- zwrócić sprawę do ponownego rozpatrzenia.

Rzecznik nie może natomiast sprawić, żeby sprawa sądowa została rozpatrzona ponownie, upomnieć sędziego lub usunąć sędziego z wykonywanego urzędu czy zmusić jakikolwiek organ do wypłaty zadośćuczynienia. Decyzja Rzecznika jest ostateczna i nie można się od niej odwołać.

W Szkocji skargi na sędziów rozpatruje Judicial Office for Scotland ${ }^{92}$. Skarga powinna zostać złożona nie później niż trzy miesiące po zdarzeniu będącym przedmiotem skargi. Skarga będzie jednak rozpatrzona dopiero po zakończeniu sprawy sądowej, włączając w to postepowanie apelacyjne. W wyjątkowych okolicznościach termin do złożenia skargi może zostać przedłużony. W Irlandii Północnej skargi na sędziów składa się do Lorda Najwyższego Sędziego Irlandii Północnej ${ }^{93}$.

\footnotetext{
89 Ibidem.

90 Ibidem, schedule 18(1).

91 Constitutional Reform Act 2005, section 101.

92 Complaints about the Judiciary (Scotland) Rules 2017.

93 Complaints about the Conduct of Judicial Office Holders Code of Practice issued by the Lord Chief Justice under Section 16 of the Justice (Northern Ireland) Act 20o2, [online:] https://judiciaryni.uk/sites/judiciary/files/media-files/14G.\%20CODE\%20OF\%2oPRACTICE\%2OJudicial\%20 \%2028\%20Feb\%2013\%20\%28Final\%29\%2oupdated\%2owith\%20 new\%2ocomp..__.pdf (dostęp: 15.03.2019).
} 


\subsection{Status sędziów Sądu Najwyższego}

Sąd Najwyższy w Wielkiej Brytanii jest najwyższą instancją sądową w sprawach cywilnych i karnych w Anglii i Walii oraz Irlandii Północnej. Kandydaci na sędziów Sądu Najwyższego nie muszą być sędziami, wystarczy że od co najmniej 15 lat posiadają prawo do występowania przez sądami wyższymi w Anglii, Szkocji lub Irlandii Północnej ${ }^{94}$ lub przez 2 lata pełnili funkcję sędziego w Sądzie Najwyższym, Angielskim Sądzie Wyższym, Angielskim Sądzie Apelacyjnym, Północnoirlandzkim Sądzie Wyższym, Północnoirlandzkim Sądzie Apelacyjnym lub Szkockim Sądzie Wyższym (ang. Court of Session) $)^{95}$.

W Sądzie Najwyższym zasiada 12 sędziów: prezes, zastępca prezesa oraz 10 sędziów. Prezes przedstawia obu izbom parlamentu coroczny raport z funkcjonowania sądu ${ }^{96}$. Sędziom, którzy nie mają tytułu szlacheckiego, nadaje się dożywotni tytuł Lorda lub Lady. Liczba sędziów może zostać zwiększona przez królową poprzez Order in Council ${ }^{97}$.

Wyboru sędziów Sądu Najwyższego dokonuje komitet, który składa się z Prezesa Sądu Najwyższego i jego zastępcy, członka Komisji ds. Nominacji Sędziowskich, członka Szkockiej Komisji ds. Nominacji Sędziowskich i członka Północnoirlandzkiej Komisji ds. Nominacji Sędziowskich ${ }^{98}$. Komisja powinna skonsultować się z sędziami mającymi rangę sędziów seniorów (ang. senior judges), a także z Lordem Kanclerzem, premierem Szkocji, premierem Walii i sekretarzem stanu Irlandii Północnej. Mianowania dokonuje królowa po zasięgnięciu opinii premiera, który otrzymuje rekomendacje Komisji ds. Nominacji Sędziowskich ${ }^{99}$.

94 Constitutional Reform Act 2005, section 25(1)(b).

95 Ibidem, section 25(1)(a).

96 Ibidem, section 51.

97 Ibidem, section $23(3)$.

98 Ibidem, schedule $8 \$ 1(1)$.

99 Ibidem, section $27(3)$. 


\section{Wnioski}

W Wielkiej Brytanii społeczeństwo ma zaufanie do systemu sądownictwa, jak i do sędziów. Korupcja w sądownictwie, w przeszłości będąca zjawiskiem powszechnym, obecnie nie jest problemem brytyjskiego wymiaru sprawiedliwości. Na sądownictwo w Wielkiej Brytanii wciąż jednak ma silny wpływ jego historia. Odnosi się to zarówno do struktury sądów, jak i do problemów społeczno-politycznych, z jakimi zmaga się wymiar sprawiedliwości.

W przeszłości urząd sędziego mogli sprawować tylko białoskórzy mężczyźni z wyższej klasy społecznej. Również współcześnie sędziami, szczególnie na wyższych stanowiskach, zostają częściej wybierani białoskórzy mężczyźni z okolic Londynu, uczęszczający do prywatnych szkól i jednego z dwóch najlepszych uniwersytetów w kraju. Kobiety, mniejszości narodowe i osoby z północy kraju mają utrudniony dostęp do urzędu, jak wynika ze statystyk na temat różnorodności wśród sędziów.

Pomimo iż urząd sędziego cieszy się obecnie wysokim prestiżem społecznym, sędziowie postrzegani są jednak często jako osoby odizolowane od reszty społeczeństwa i problemów społecznych. To odseparowanie sędziów, również w sensie geograficznym, sprawia, iż problemy reszty społeczeństwa, np. z dostępem do dóbr materialnych, służby zdrowia, szkolnictwa mogą być postrzegane przez sędziów wyłącznie z punktu widzenia klasy uprzywilejowanej.

W środowisku naukowym uznaje się, iż system powoływania sędziów odzwierciedla stereotypowe postrzeganie sędziego jako białoskórego mężczyzny o określonym pochodzeniu. Ustawodawstwo odpowiedziało na to wyzwanie poprzez wprowadzenie zasady różnorodności przy mianowaniu sędziów. Zgodnie z ustawą, decydującą rolę pełnią jednak przesłanki merytoryczne i wymóg dobrego charakteru.

Przesłanka dobrego (czy nieskazitelnego) charakteru jest istotnym kryterium przy mianowaniu na stanowisko. Interesującym aspektem wymogu posiadania dobrego charakteru przez brytyjskich sędziów jest jednak sposób jego uzasadnienia. Komisja ds. Nominacji Sędziowskich uzasadnia ten wymóg następująco: 
Zasady, które Komisja zaadoptowała przy określaniu dobrego charakteru, opierają się na nadrzędnej potrzebie utrzymania publicznego zaufania do standardów sądownictwa oraz na tym, że zaufanie publiczne zostanie utrzymane tylko wtedy, gdy osoby sprawujące urząd sądowy i osoby aspirujące do pełnienia takiej roli utrzymają najwyższe standardy zachowania w życiu zawodowym, publicznym i prywatnym ${ }^{100}$.

Ten nacisk na postrzeganie sędziów w opinii publicznej może sprawić, iż nieetyczne zachowania mogą być ukrywane w środowisku sędziowskim i przez organy powołane do przeciwdziałania takim zachowaniom wśród sędziów w obawie, iż mogą one doprowadzić do utraty zaufania opinii publicznej względem sędziów.

Zgodnie z wymogami Komisji ds. Nominacji Sędziowskich, sędzia o nieskazitelnym charakterze to taki, który nie popełnia przestępstw ani wykroczeń, płaci podatki, jest wypłacalny i wobec którego nie toczą się postępowania dyscyplinarne. Spełnianie tych warunków to jednak podstawowe i minimalne wymagania, które powinien spełniać każdy obywatel ${ }^{101}$. Wydaje się więc, że używanie tych kryteriów jako miary dobrego charakteru dla zawodu o tak istotnym wpływie na prawa i obowiązki innych nie jest wystarczające. Co więcej, nawet te minimalne wymagania etyczne względem sędziów są interpretowane przez Komisję, jak sama przyznaje, „bardzo szeroko"102.

Również po mianowaniu od sędziów wymaga się, aby kierowali się etyką podczas wykonywania zawodu. Nad przestrzeganiem etyki zawodowej czuwa Rzecznik ds. Nominacji i Postępowania Sądowego, odpowiedzialny

\footnotetext{
$100 \quad$ Ibidem, pkt 9.

101 Wymagania etyczne stawiane przedstawicielom innych profesji w Wielkiej Brytanii są stosunkowo wyższe, por. S. Earl, M. Moulin-Stozek, Moving Towards Virtuous Professional Practice: A Summary of a Content Analysis of Professional Regulatory Documents and Codes of Conduct, University of Birmingham, 2019, [online:] https://www.jubileecentre.ac.uk/ userfiles/jubileecentre/pdf/insight-series/MovingTowardsVirtuousProfessionalPractice. pdf (dostęp: 15.03.2019).

102 Komisja ds. Nominacji Sędziowskich, Good character guidance, [online:] https:// www.judicialappointments.gov.uk/sites/default/files/sync/good-character-guidance-jan2019.pdf (dostęp: 15.05.2019).
} 
nie tylko za wydawanie zaleceń dotyczących procesu mianowania sędziów, ale także przyjmowanie skarg na sędziów.

Podsumowując, największym wyzwaniem sądownictwa brytyjskiego jest obecnie implementacja zasady różnorodności. Niewątpliwie również w innych krajach sędziowie wywodzą się z elit społecznych i absolwentów najlepszych uniwersytetów. W Wielkiej Brytanii jednak zawód ten wykonują często osoby o określonym kapitale kulturowym i wywodzące się z konkretnego środowiska. Odpowiedzią na to wyzwanie było powołanie Komisji ds. Nominacji Sędziowskich, Rzecznika ds. Nominacji i Postępowania Sądowego czy obecność obserwatorów podczas rozmów rekrutacyjnych na stanowiska sędziowskie. Pomimo tego, funkcjonowanie systemu mianowania sędziów jest krytykowane również w środowiskach sędziowskich, które uznają, że w rzeczywistości nie jest on całkowicie przejrzysty i oparty na przesłankach merytorycznych. 